\title{
DAMPAK PERNIKAHAN BEDA AGAMA TERHADAP KETERLIBATAN HIDUP MENGGEREJA SEBAGAI UMAT BERIMAN KRISTIANI
}

\author{
Hendri Kusnadi, Albert I Ketut Deni Wijaya*) \\ STKIP Widya Yuwana \\ andyputracerdas@gmail.com \\ *) penulis korespondensi, albert.deni@widyayuwana.ac.id
}

\begin{abstract}
Marriage is a partnership between man and woman who have been baptized. It is monogamous and inseverable in nature. Dealing with the characteristic of catholic marriage, the church forbids the mixed marriage to occur. The prohibition is an attempt of the church to protect the Catholics' faith from the risk of mixed marriage. In the other hands, the church creates a policy which is in the form of permission for mixed marriage. Further, this kind of marriage has impacts towards the church life. One of the impacts is causing intolerance in which the Catholics become inactive in the church life. Regarding the effect of interfaith marriage towards the involvement of church life as Christians, some problems are formulated such as : 1) what is the definition of interfaith marriage? 2) how is the church life of the people who commit interfaith marriage as Christians3) What are the effects of interfaith marriage towards their church life?

In this research, Qualitative method is applied. Mean while, the method of interviewing (structural) is used to collect the data. The direct interviews are conducted privately between the parties. Moreover, the respondents of this research are the Catholics who undertake a mixed marriage at chapelry of Saint VincentiusA Paulo Jenangan.

Based on the result of the research, there are three things which are found. First, people have lack of understanding about interfaith marriage. They are unable to differentiate between mixed marriage of different religion or church. Besides, they do not really understand the process of gaining permission to undertake the marriage. Second, people are not active in doing the activities in the church. They said that they only involved in 2 fields out of 5 church duties. Furthermore, there are negative effects of interfaith marriage, that is the intolerance of a party who is not catholic. In the case, the intolerance itself is the different opinion which causes anger and always be brought up. However, there are also some positive effects which appears from interfaith marriage. One of them is the tolerance of a non-Catholic party who always reminds his or her partner to go to the church.
\end{abstract}

Keywords : Effect of Interfaith Marriage, Interfaith Marriage, Church life 


\section{PENDAHULUAN}

Dalam status sosialnya di tengah masyarakat, manusia ditentukan oleh dua pilihan hidup. Status sosial ini ditentukan oleh hidup menikah atau hidup selibat. Menikah adalah salah satu pilihan yang perlu dihayati arti dan nilainya. Supaya mengerti arti dan nilai perkawinan, manusia perlu belajar tentang seputar perkawinan. Perkawinan adalah persekutuan antara pria dan wanita yang diciptakan dan diberkati Allah. Kejadian 1:27-28 memberikan arti dan nilai tentang perkawinan. Allah menciptakan manusia (laki-laki dan perempuan) menurut gambar Allah sendiri. Allah memberkati manusia ini supaya beranak cucu dan bertambah banyak, serta berfirman kepada manusia supaya memelihara ciptaan Allah yang lain (Hadiwardoyo, 1988: 13).

Pria dan wanita menyatakan janji untuk hidup dalam persekutuan, baik secara jasmani maupun secara rohani. Persekutuan hidup ini menuju kepada hadirnya ketenangan, kebahagiaan dan ketentraman bersama suami-istri (Christy, 2012: 43). Kebahagaiaan perkawinan tidak hanya ditentukan oleh harta yang berlimpah, tetapi juga oleh rasa cinta dan rasa saling memiliki (Christy, 2012: 72). Perkawinan perlu direncanakan dalam waktu yang cukup lama. Rencana ini meliputi masa perkenalan, masa pacaran dan terakhir adalah keputusan untuk menikah (Raharso, 2006: 254). Perkawinan yang sudah menjadi kesepakatan antara pria dan wanita serta kesepakatan antar keluarga, akan disahkan dalam hukum Gereja dan hukum sipil (Raharso, 2006: 254).

Perkawinan antara orang Katolik dan bukan Katolik dalam Gereja Katolik disebut sebagai halangan. Gereja Katolik melarang terjadinya perkawinan antara orang Katolik dan bukan Katolik. Larangan ini merupakan bentuk antisipasi akan dampak yang ditimbulkan dari pernikahan yang beda agama. Pernikahan beda agama sering menimbulkan perbedaan mengenai praktik hidup sosial dan kehidupan beribadah (Go, 1992: 12). Perbedaan pandangan ini dapat menimbulkan tekanan diantara salah satu pihak, dimana yang kuat akan menekan yang lemah dan bahkan sebaliknya yang lemah akan semakin ditekan. Tekanan ini dapat menyebabkan rasa kecewa, rasa malas sehingga pihak yang ditekan menjadi tidak terlibat aktif dalam kegiatan menggereja (Suparto, 2009:39).

Gereja Katolik melarang terjadinya perkawinan campur beda agama. Larangan ini didasarkan pada sifat dari perkawinan Katolik yang monogam dan tak terceraikan serta bahaya dari pernikahan beda agama. Pernikahan beda agama dipandang dapat membahayakan perkembangan iman dari pihak Katolik (Go, 1992: 10). Pernikahan beda agama memberikan dampak bagi kehidupan rohani umat beriman Kristiani yang menikah beda agama. Berdasarkan hal-hal tersebut, maka muncullah beberapa pertanyaan. Pertanyaan yang paling menonjol adalah bagaimana keterlibatan hidup menggereja umat beriman Kristiani yang 
menikah campur beda agama? Apa dampak pernikahan beda agama terhadap keterlibatan umat yang menikah beda agama dalam hidup meggereja?

\section{PERNIKAHAN CAMPUR BEDA AGAMA}

\subsection{Pandangan Gereja terhadap Pernikahan Campur}

Gereja Katolik menetapkan aturan pelaksanaan perkawinan Katolik. Aturan ini memperhatikan tata pelaksanaan dan liturgi dalam perkawinan (Prihartana 2008:27). Perkawinan Katolik mengarah pada dua aspek yakni teknis dan yuridis. Teknis ini ialah menyangkut perkawinan Katolik yang harus dirayakan dalam Gereja Katolik. Yuridis ialah perkawinan harus dilaksanakan sesuai hukum Gereja.

Hukum Gereja Katolik menuntut perkawinan yang sakramen. Perkawinan yang sakramen ialah perkawinan antara dua orang yang sama-sama sudah dibaptis. Perkawinan antara orang yang sudah dibaptis dalam gereja Katolik dan orang diluar gereja Katolik merupakan halangan (Kriswanta, 2012: 33-34). Perkawinan antara orang Katolik dan bukan Katolik disebut sebagai perkawinan campur. Perkawinan campur ada dua jenis yakni perkawinan campur beda agama (disparitas cultus) dan perkawinan campur beda Gereja (mixta relegio).

\subsubsection{Perkawinan Campur Beda Agama (disparitas cultus)}

Kawin campur beda agama ialah perkawinan antara orang yang dibaptis dalam gereja Katolik dan orang yang tidak dibaptis. Orang yang tidak dibaptis ialah orang yang menganut agama islam, hindu, buddha dan konghucu (Prihartana, 2012: 35). Gereja katolik memiliki aturan dan ketentuan mengenai pola dan tingkah laku dalam perkawinan. Aturan ini menyangkut adanya larangan pernikahan campur beda agama. Pernikahan campur beda agama disebut sebagai halangan perkawinan (Prihartana, 2008: 17). Halangan ini menurut ketentuan hukum Gereja, dapat membatalkan perkawinan.

Pernikahan campur beda agama kenyataannya sering terjadi di tengah masyarakat. Gereja dijadikan sebagai bahan pertimbangan, khususnya mengenai hak kodrati manusia dalam menentukan pilihan. Pandangan ini menjadikan Gereja menentukan sikap, yakni dengan memberikan dispensasi nikah campur. Dispensasi nikah campur merupakan keringanan yang diberikan oleh Gereja supaya perkawinan antara orang Katolik dan orang bukan Katolik menjadi sah (Kriswanta, 2012: 38). Dispensasi ialah serangkaian proses yang dimulai dari laporan pihak Katolik kepada romo paroki, kemudian adanya penyidikan kanonik dan pemenuhan syarat dari pihak Katolik. Syarat ini harus dipenuhi supaya dapat memperoleh dispensasi. Dispenasi hanya bisa diberikan oleh Uskup Diosesan (Kriswanta 2012: 39-40). 


\subsubsection{Pernikahan Campur Beda Gereja (mixta Relegio)}

Pernikahan campur beda Gereja ialah pernikahan antara orang yang dibaptis Katolik dengan orang protestan. Perkawinan campur beda Gereja dianggap sebagai halangan perkawinan. Halangan ini menjadi larangan yang tidak menggagalkan perkawinan. Larangan ini mengandaikan bahwa perkawinan tidak layak dilangsungkan begitu saja (Kriswanta, 2012: 43). Supaya layak maka perkawinan beda Gereja perlu mendapatkan izin dari ordinaris wilayah (Kriswanta, 2012: 43). Izin ini dapat diperoleh dengan cara pihak Katolik memberikan laporan dan meminta izin dari pastor paroki. Pastor paroki akan melakukan penyidikan kanonik dan meminta syarat dari pihak Katolik, setelah proses ini selesai pastor paroki akan memberi tembusan kepadan Uskup Diosesan (Kriswanta, 2012: 4).

Syarat yang harus dipenuhi berkaitan dengan kesediaan pihak Katolik untuk berpegang teguh pada iman Katolik. Pihak Katolik harus berupaya untuk memupuk dan menumbuhkembangkan imannya. Pihak Katolik juga harus berupaya agar anaknya dididik dan dibaptis dalam Gereja Katolik. Menjaga iman dan mendidik anak merupakan kewajiban dari pihak Katolik. Kewajiban ini hendaknya diberitahukan kepada pihak bukan Katolik supaya sadar dan paham akan janji dan kewajiban pihak Katolik. Pihak Katolik dan bukan Katolik harus diberikan kursus perkawinan, supaya mengerti tentang hakikat dan nilai perkawinan menurut Katolik (Kriswanta, 2012: 4).

\section{Dampak Pernikahan Campur}

Aturan Gereja mengenai pernikahan campur didasari oleh adanya kemungkinan bahaya yang ditimbulkan dari pernikahan campur. Salah satu aturan yang diberikan Gereja, ialah adanya syarat yang harus dipenuhi dalam memperoleh izin/dispensasi (Rubiyatmoko, 2011: 75-76). Syarat ini meliputi janji pihak Katolik untuk teguh terhadap iman, mendidik anak secara Katolik dan berusaha menjaga nilai-nilai perkawinan (Go, 1990: 51).

Untuk mendapatkan izin pernikahan campur, pihak Katolik perlu memenuhi syarat yang ditentukan oleh Gereja. Gereja memberikan syarat sebagai upaya untuk menghindari dampak dari pernikahan campur. Pernikahan campur membawa tiga kemungkinan dampak, yakni bahaya terhadap iman pihak Katolik, kebingungan terhadap pendidikan anak dan ancaman terhadap hakikat perkawinan Katolik (Go, 1990: 51).

\subsubsection{Sakramen Perkawinan}

Gereja Katolik memandang perkawinan sebagai lambang kasih Allah terhadap umat-Nya. Lambang ini harus dihayati dalam perkawinan dengan menekankan kesetiaan dan cinta suami-istri (Kriswanta, 2012: 33). Perkawinan 
menjadi sarana hadirnya Allah sehingga perkawinan ini bersifat kesatuan dan tak terceraikan (Kriswanta, 2012: 39-41).

Pernikahan campur menimbulkan bahaya perceraian. Perceraian dapat terjadi karena pandangan dan aturan agama yang memperbolehkan terjadinya perceraian. Aturan ini dapat dianggap benar oleh pasangan yang bukan Katolik, maka aturan ini sangat bertentangan dengan pandangan Gereja Katolik mengenai hakikat perkawinan sebagai sakramen (Gunawan, 2000: 19).

\subsubsection{Kehidupan Iman Gereja}

Herkulanus Entangai (2004:19) mengatakan bahwa pernikahan campur dapat membahayakan pihak iman Katolik. Bahaya ini muncul karena adanya sikap intoleran dari pihak bukan Katolik. Sikap intoleran dapat saja menghambat perkembangan iman pihak Katolik.

Ariarajah (2008: 95) mengatakan bahwa sikap intoleran ini bisa saja muncul karena perbedaan latar belakang budaya dan tradisi agama yang dianut. Perbedaan latar belakang ini menjadikan suami-istri berpegang pada prinsip dan nilai agama masing-masing. Prinsip yang dipegang oleh suami-istri dalam pernikahan campur dapat menenggelamkan nilai-nilai toleransi. Hardiwiratno (2008: 143) mengatakan bahwa sikap intoleran ini dapat saja berupa tekanan salah satu pihak terhadap pihak lain sehingga pihak yang ditekan tidak bebas melaksanakan tanggung jawab agamanya.

\subsubsection{Pendidikan Anak}

Pernikahan campur membawa dua pandangan agama yang berbeda. Pandangan ini berpengaruh besar bagi pendidikan iman anak dalam keluarga. Anak akan merasa bingung menentukan pilihan tentang agama mana yang harus dianut (Hardiwiratno, 2008: 143). Kebingungan ini menjadikan pendidikan anak dalam keluarga perkawinan campur menjadi sulit. Kesulitan terjadi, ketika pihak Katolik harus melaksanakan kewajiban dan tanggungjawabnya untuk mendidik anaknya secara Katolik. Mendidik anak juga disisi lain merupakan tugas dan tanggung jawab kedua orangtua (Hardiwiratno, 2008:143).

Anak dalam perkawinan campur, sekaligus menerima dua ajaran agama yang berbeda, hal ini menjadikan anak bingung dalam menentukan keyakinan yang harus dianut. Kebingungan ini menjadikan anak tidak aktif dalam kegiatan Gereja dan tidak memiliki status agama yang jelas (bingung memilih agama).

\subsubsection{Tugas dan Kewajiban Suami Istri dalam Pernikahan Campur}

Tugas dan kewajiban suami istri dalam pernikahan campur ialah merawat dan menjaga anak. Anak merupakan anugerah dari Allah yang harus diarahkan dan dididik supaya selamat (Supriyadi, 2018:31). Keselamatan anak sangat 
ditentukan oleh peran orangtua khususnya pihak Katolik dalam melaksanakan kewajibannya untuk mendidik anak dalam iman Katolik. Peran ini menjadi bagian dari perpanjangan tangan Gereja untuk membawa manusia pada keselamatan. Gereja menaruh harapan agar umat beriman Kristiani yang menikah campur dapat mendidik anaknya dengan sungguh-sungguh (Prihartana, 2008: 6 bdk. Go, 1990: 38).

Sifat perkawinan Katolik menjadi fokus perhatian gereja khususnya mengenai kekuatiran akan bahaya pernikahan campur. Pernikahan campur oleh Gereja Katolik tetap dituntut untuk memelihara nilai sakramentalitas perkawinan, sehingga pasangan perkawinan campur diajar mengenai seputar perkawinan (Rubiyatmoko, 2011: 76). Sakramentalitas perkawinan menunjukkan bahwa perkawinan campur tetap memiliki sifat monogam dan tak terceraikan (Kriswanta, 2012: 39).

\section{Hidup Menggereja Umat Beriman}

Hidup menggereja merupakan bagian yang tidak bisa dipisahkan dari kehidupan umat beriman Kristiani. Umat beriman ini dapat menumbuhkembangkan iman melalui kegiatan hidup menggereja. Hidup menggereja dapat diungkapkan melalui keterlibatan dalam panca tugas gereja. Panca tugas gereja tersebut meliputi: koinonia, diakonia, liturgia, keryigma dan martyria.

Koinonia berasal dari bahasa latin yang artinya mengambil bagian. Ambil bagian artinya ikut terlibat dalam berbagai kegiatan gereja serta berinteraksi dengan satu sama lain sebagai anggota gereja. Interaksi antara anggota gereja dapat membangun kehidupan yang guyub dan rukun. Kehidupan guyub dan rukun dapat menciptakan sebuah persekutuan dalam gereja. Persekutuan ini membentuk cita-kasih dan persaudaraan yang tumbuh melalui keterlibatan dalam berbagai kegiatan gereja (Suwita, 2002: 8-9).

Diakonia merupakan bentuk cinta-kasih yang diwujudnyatakan melalui kegiatan pelayanan terhadap sesama. Pelayanan ini ialah ugkapan kasih, sikap rendah hati, pengampunan dan dapat berbentuk pemberian rasa aman bagi orang yang dilayani. Diakonia tidak bisa lepas dari cinta-kasih dan persaudaraan antar sesama manusia. Kasih dan persaudaraan ini merupakan wujud dari kasih Kristus terhadap umat-Nya (Suwita, 2002: 97).

Liturgia merupakan semua kegiatan yang berhubungan dengan peribadatan. Liturgia merupakan tradisi turun temurun dan tidak bisa dipisahkan dari kehidupan umat beriman Kristiani. Umat beriman Kristiani memiliki kewajiban untuk ikut terlibat dalam kegiatan liturgi. Keterlibatan ini dapat berupa kehadiran atau melibatkan diri menjadi pelayan dalam kegiatan liturgi. Kegiatan liturgi ini membawa umat pada pengenangan akan sengsara dan kebangkitan 
Kristus. Mengenang sengsara wafat dan kebangkitan Kristus dapat menjadikan umat semakin sadar serta tumbuh dan berkembang dalam iman (Utami, 2018:179).

Keryigma merupakan tugas mengajar yang dilakukan oleh gereja. Tugas mengajar ini ialah upaya untuk menyampaikan kabar gembira tentang kerajaan Allah. Kabar gembira ini disampaiakan kepada seluruh umat manusia supaya dapat menemukan kebenaran sejati. Kebenaran akan kerajaan Allah ini harus dijaga dan dipelihara dengan mendasarkan pada sikap dan tingkah laku sesuai ajaran iman Kristiani (Suwita, 2001: 9).

Martyria dalam kamus besar mengarah pada pegertian mengenai saksi. Saksi merupakan orang yang melihat suatu peristiwa dan kemudian memberitakan keterangan megenai peristiwa tersebut sesuai kronologinya. Keterangan yang diberikan atas peristiwa yang sudah terjadi disebut sebagai kesaksian. Kesaksian dalam bahasa Yunani ialah marturion yang berarti martir. Martir ialah orang yang menderita dan mati demi kebenaran (agama). Kebenaran tersebut berasal dari Allah yang membawa semua orang pada hidup damai, sejahtera dan kekal (Priyanto, 2017:98-99).

\subsection{Gambaran Keluarga Pernikahan Campur Beda Agama}

Bernard Raho (2003:137-141) mengatakan bahwa keberhasilan perkawinan ditentukan oleh kelanggengan perkawinan, kebahagiaan menyeluruh dan kepuasan dalam aspek tertentu. Perkawinan yang berhasil ditentukan juga oleh pendidikan, ekonomi dan rasa keagamaan. Bernard Raho (2003:141) mengungkapkan bahwa rasa keagamaan berpengaruh terhadap penyesuaian diri dalam perkawinan. Rasa keagamaan ini menyangkut pengalaman keagamaan yang dapat membawa seseorang pada penghayatan akan nilai keagamaan dalam perkawinan.

Bernard Raho (2003:141) mengatakan bahwa rasa keagamaan dipengaruhi oleh pandangan agama mengenai suatu nilai yang dianut. Nilai agama ini biasanya selalu berusaha untuk dijaga dan dipertahankan. Mempertahankan nilai agama tertentu akan menimbulkan masalah jika tidak diimbangi dengan sikap toleran. Sikap toleran ini perlu dikembangkan khususnya dalam pernikahan campur.

\section{HASIL PENELITIAN DAMPAK PERNIKAHAN BEDA AGAMA TERHADAP KETERLIBATAN HIDUP MENGGEREJA SEBAGAI UMAT BERIMAN KRISTIANI}

Penelitian ini menggunakan metode penelitian kualitatif yang dilakukan terhadap umat beriman Kristiani yang menikah beda agama di Stasi St. Vincentius A Paulo Jenangan Paroki St. Cornelius Madiun, pada bulan April tahun 2019. Untuk memperoleh data penelitian, metode yang digunakan adalah wawancara 
secara terstruktur. Wawancara dilakukan secara pribadi antara peneliti dan responden (Sugiyono, 2006: 253).

Penelitian ini bertujuan untuk mengetahui dampak dari pernikahan beda agama terhadap keterlibatan hidup menggereja sebagai umat beriman Kristiani. Untuk mengetahui dampak ini maka ditentukanlah dua indikator, yakni; 1) keterlibatan hidup menggereja umat yang menikah campur beda agama sebagai umat beriman Kristiani; 2) dampak pernikahan beda agama terhadap keterlibatan hidup menggereja umat (umat yang menikah beda agama) sebagai umat beriman Kristiani. Kemudian masing-masing indikator ini dibagi kedalam beberapa instrumen penelitian.

\subsection{Keterlibatan Hidup Menggereja Umat yang Menikah Campur Beda Agama sebagai Umat Beriman Kristiani}

Indikator ini diukur melalui dua instrumen. Instrumen pertama, keterlibatan umat beriman Kristiani dalam panca tugas Gereja dan dampak pernikahan beda agama dalam hidup menggereja. Ditemukan sebanyak 3 (tiga) responden ikut terlibat dalam bidang liturgia. Bidang liturgia yang diikuti ialah jalan salib, ibadat lingkungan dan terlibat dalam tugas lektor. Sedangkan 2 (dua) responden terlibat dalam bidang kerygma. Bidang keriygma yang diikuti yaitu pendalaman kitab suci, selain itu dua (2) responden terlibat dalam bidang koinonia. Bidang koinonia yang diikuti ialah WKRI, kerja bakti dan arisan lingkungan.

Gereja Katolik mengenal lima aspek dalam kehidupan menggereja. Aspek ini dijadikan sebagai ukuran keterlibatan hidup menggereja umat beriman Kristiani. Aspek pertama ialah koinonia atau sering disebut dengan persekutuan. Koinonia mengarah pada sikap solidaritas yang dibangun bersama melalui keterlibatan dalam berbagai kegiatan menggereja. kegiatan menggereja yang masuk kriteria koinonia ialah WK, kerja bakti, piket di gereja, arisan dan kegiatan lingkungan (Suwita, 2002: 8-9). Aspek kedua ialah diakonia atau disebut sebagai bidang pelayanan. Diakonia mengarah kepada bentuk cinta-kasih yang diwujudkan dengan memberikan pelayanan terhadap sesama. Kasih ini dimaknai sebagai kasih terhadap Allah. Tindakan kasih tersebut dapat dilakukan melalui kegiatan BANSOS/ bantuan sosial dan PSE/pengembangan sosial ekonomi (Suwita, 2002: 97). Selanjutnya, kegiatan liturgia atau sering disebut bidang peribadatan. Liturgia merupakan tradisi gereja Katolik yang sudah menjadi tradisi secara turun temurun. Tradisi ini tidak bisa dipisahkan dari kehidupan umat beriman Kristiani dalam menumbuhkembangkan imannya. Umat beriman melalui kegiatan liturgi ini dibawa pada penghayatan akan sengsara dan wafat Kristus dikayu salib. Kegiatan yang termasuk dalam bidang liturgi ialah jalan salib, doa rosario, BKSN dan misa (Suwita, 2002: 48). Kemudian bidang pewartaan atau 
sering disebut kerygma. Kerygma ialah tugas mengajar yang dilakukan oleh Gereja supaya kabar gembira sampai kepada umat manusia. Pengajaran ini merupakan sarana untuk mewartakan kebenaran tentang kerajaan Allah. Kebenaran tersebut harus dijaga dan dipelihara dengan mendasarkan pada ajaran Kristiani. kegiatan yang termasuk dalam bidang kerygma ialah kegiatan pembinaan BIAK dan OMK (Suwita, 2001: 9). Selanjutnya ialah martirya atau sering disebut kesaksian. Martirya menurut Kamus Besar Bahasa Indonesia (KBBI) dapat diartikan sebagai saksi. Saksi ialah orang yang menyampaikan atau memberitakan suatu peristiwa sesuai dengan alur peristiwa itu terjadi. Pemberitaan ini disebut sebagai kesaksian. Kesaksian dalam bahasa Yunani ialah marturion yang berarti martir. Martir ialah orang yang menderita dan mati demi kebenaran (agama). Kebenaran tersebut berasal dari Allah yang membawa semua orang pada hidup damai, sejahtera dan kekal (Suwita, 2001: 39-40). Kesaksian dalam iman Kristiani menjadi bagian dalam melaksanakan lima tugas Gereja. Kesaksian ini dapat diaplikasikan kedalam tindakan, sikap dan tingkah laku yang menceriminkan sebagai murid Kristus. Kegiatan yang termasuk dalam bidang martirya ialah kunjungan (Suwita, 2002: 10).

Berdasarkan data hasil penelitian, dapat disimpulkan bahwa keterlibatan responden dalam panca tugas gereja masih sangat kurang. Keterlibatan ini jika dikelompokkan kedalam lima tugas gereja, paling banyak responden hanya terlibat dalam dua bidang kegiatan dari lima tugas Gereja. Sedangkan yang lainnya hanya mengikuti satu bidang kegiatan dari lima tugas Gereja.

Instrumen kedua mendalami dampak pernikahan beda agama dalam hidup menggereja. Berdasarkan instrumen ini, ditemukan adanya dampak pernikahan beda agama bagi hidup menggereja umat beriman Kristiani. Dampak tersebut muncul karena adanya perbedaan pandangan yang dapat menimbulkan kemarahan dan masalah yang selalu dibawa-bawa. Masalah ini menjadikan responden tidak fokus dalam mengikuti kegiatan menggereja dan banyak kegiatan menjadi tersita.

Masalah hidup menggereja melalui kajian teori dapat dipetakan sesuai permasalahan yang dihadapi oleh responden. Masalah pertama ialah adanya bahaya terhadap iman pihak Katolik. Bahaya yang muncul berupa sikap intoleran dari pihak non Katolik. Sikap intoleran ini berupa permasalahan yang selalu dibawa-bawa. Untuk itu, pihak Katolik merasa tertekan yang kemudian menyebabkan tidak fokus dalam mengikuti kegiatan. Tekanan ini juga menyebabkan banyak kegiatan Gereja menjadi tersita. sikap intoleran ini dapat menghambat perkembangan iman pihak Katolik. Sikap intoleran tersebut muncul karena perbedaan pandangan dan latar belakang agama yang berbeda (Lih. Ariarajah, 2008: 95).

Berdasarkan data yang diperoleh, dapat disimpulkan mengenai adanya sikap intoleran yang timbul dari pernikahan beda agama terhadap hidup 
menggereja. Hal tersebut menjadi bahaya bagi iman pihak Katolik dimana responden menjadi tidak fokus dalam mengikuti kegiatan gereja dan juga banyak kegiatan gereja menjadi tersita.

\subsection{Dampak Pernikahan Beda Agama terhadap Keterlibatan Hidup Menggereja Umat}

Indikator ini dibagi kedalam empat instrumen. Instrumen pertama ialah dampak positif pernikahan beda agama dalam hidup menggereja. Berdasarkan instrumen tersebut ditemukan adanya dampak positif dari pernikahan beda agama. Dampak positif ini berupa sikap toleran pihak non Katolik dimana pihak Katolik selalu diingatkan untuk pergi ke gereja. Selain itu, pihak Katolik harus berusaha memahami dan harus bisa menjadi contoh. Kemudian ada juga responden yang mengatakan tidak ada masalah. Selain itu ada pula responden mengatakan cukup diambil maknanya saja.

Berdasarkan data yang diperoleh dapat disimpulkan dua hal terkait dampak positif pernikahan beda agama. Pertama, ada pihak bukan Katolik yang bersikap toleran yang diungkapkan dengan mengingatkan untuk pergi ke gereja. Kedua, dibalik sikap toleran tersebut, responden mengambil langkah bijak untuk mengatasi dampak negatif yang timbul. Langkah bijak ini dilakukan dengan berupaya memahami dan menjadi contoh baik bagi pihak bukan Katolik. Kemudian, kalau ada masalah diambil maknanya saja.

Instrumen kedua ialah dampak negatif dari pernikahan beda agama. Berdasarkan instrumen ini diperoleh bahwa pernikahan beda agama menimbulkan dampak negatif. 3 (tiga) responden mengatakan dampak negatif yang timbul ialah kegiatan gereja menjadi tersita. Selain itu, (1) satu responden mengatakan memang ada masalah tetapi ditanggapi dengan sikap cuek saja. (1) Satu responden lagi mengatakan tidak ada masalah dalam hidup menggereja.

Berdasarkan jawaban yang disampaikan responden dan melihat kajian teori, memang ada dampak yang timbul dari pernikahan beda agama tersebut. Dampaknya berupa sikap intoleran dari pihak bukan Katolik. Sikap intoleran ini dapat menghambat perkembangan iman pihak Katolik. Dimana (3) tiga responden mengatakan bahwa kegiatan gereja menjadi tersita. Kemudian ada responden yang mengatakan bersikap cuek terhadap maslah yang ada. Tetapi sisi lain ada responden yang mengatakan tidak ada masalah bagi hidup menggerejanya.

Data hasil wawancara dapat disimpulkan bahwa pernikahan beda agama menimbulkan dampak negatif. Dampak negatif ini muncul karena adanya sikap intoleran dari pihak bukan Katolik Dengan demikian sikap intoleran (dampak negatif pernikahan beda agama) menjadi bahaya terhadap iman pihak Katolik.

Instrumen ketiga ialah upaya mengatasi dampak negatif yang muncul dari pernikahan beda agama. Hasil data wawancara menunjukkan kalau upaya yang 
dilakukan (3) tiga responden dalam menghadapi dampak negatif pernikahan beda agama adalah bersikap sabar. Ada (2) dua responden mengatakan harus bersikap cuek. Selain itu, (2) dua responden mengatakan harus berupaya saling menghormati dan (3) tiga responden mengungkapkan saling memahami, tidak mau dipengaruhi dan harus bisa memilah.

Berdasarkan kajian teori dan melihat jawaban responden, ditemukan enam jenis upaya yang dilakukan untuk membangun sikap toleran dan kerjasama dalam pernikahan campur beda agama. Upaya ini berupaya membangun sikap toleran dengan berupaya bersikap sabar, saling menghargai dan saling mengerti. Upaya ini dapat menciptakan kerjasama yang baik dan menciptakan ruang bagi pihak Katolik untuk menumbuhkembangkan imannya (Lih. KWI, 2011: 43). Kemudian ada beberapa responden yang bersikap tegas terhadap dampak negatif dari pernikahan beda agama. Sikap tegas ini ialah tidak mau dipengaruhi dan berupaya bersikap kritis dan memilah jika ada masalah (Lih. Wuarmanuk, 2018:19). Sedangkan satu responden mengatakan dengan bersikap masa bodoh.

Kesimpulan terhadap data hasil penelitian bahwa untuk mengatasi dampak negatif dari pernikahan beda agama, para responden berupaya membangun sikap toleran, berusaha bersikap sabar dan saling menghargai. Selain itu, perlu ada sikap tegas yakni tidak mau dipengaruhi dan kritis terhadap masalah. Dengan demikain dapat tercipta ruang bagi pihak Katolik dalam menjalankan kewajiban sebagai umat beriman Kristiani.

Instrumen keempat ialah perhatian gereja terhadap dampak negatif pernikahan beda agama. Perhatian yang diberikan gereja sangat bervariasi. (4) empat responden mengatakan bahwa ketua stasi sering memberikan pandangan, (2) dua responden mengatakan ketua stasi sering memberi nasehat, (1) satu responden mengungkapkan kalau ketua stasi memberikan motivasi, (1) satu responden menyatakan sering dikunjungi teman-teman gereja, selain itu ada yang mengatakan bahwa ketua stasi sering memberi renungan, kemudian (1) satu responden mengharapkan adanya kunjungan dari romo paroki.

Ketua stasi sebagai petugas pastoral setempat melakukan upaya yang cukup baik terhadap permasalahan responden. Berdasarkan analisa terhadap data penelitian dapat disimpulkan bahwa gereja setempat sudah memberikan perhatian yang cukup terhadap permasalahan responden. Perhatian ini berupa pemberian pandangan, nasihat, motivasi, renungan serta kunjungan dari teman-teman gereja, akan tetapi ada harapan dan kerinduan responden untuk dikunjungi oleh romo paroki.

\section{KESIMPULAN}

Keterlibatan umat dalam hidup menggereja. Dari hasil penelitian dan berdasarkan pernyataan umat sendiri bahwa umat kurang terlibat secara aktif 
dalam kegiatan hidup menggereja. Umat juga dalam hal ini mengatakan bahwa mereka paling banyak terlibat dua bidang kegiatan dari lima tugas gereja. Dua bidang tugas gereja ini terbagi menjadi sepuluh jenis kegiatan. Sebagai catatan, lima bidang hidup gereja itu saling terkait satu sama lain. Diakonia dan martyria bisa terjadi di dalam kegiatan liturgi ataupun kegiatan sosial mereka sebagai orang Katolik. Tentu tidak begitu saja dengan mudah mengatakan bahwa mereka hanya terlibat dalam koinonia dan liturgia saja. Ada kemungkinan juga bahwa mereka terlibat dalam bidang tugas yang lain tetapi umat tidak berani menyatakan atau mengklaimnya.

Dampak pernikahan campur bagi hidup menggereja umat beriman Kristiani. Berdasarkan data hasil penelitian diperoleh bahwa pernikahan campur memberikan dua dampak bagi hidup menggereja umat, yakni dampak negatif dan positif. Dampak negatif yang muncul dalam bentuk perbedaan pendapat dan masalah yang selalu diungkit, sedangkan dampak positif dari pernikahan campur beda agama ialah adanya sikap toleransi. Sikap toleransi tersebut ditunjukkan dengan sikap pihak bukan Katolik yang selalu mengingatkan pasangannya untuk pergi ke gereja. Upaya umat mengatasi dampak negatif pernikahan beda agama dengan membangun sikap toleransi, berusaha sabar, saling menghargai dan bersikap tegas. Selain itu juga Gereja setempat memberikan perhatian terhadap umat. Perhatian yang diberikan ialah dengan memberi nasihat, memberi pandangan, motivasi, renungan, wawasan dan kunjungan oleh teman-teman gereja. 


\section{DAFTAR PUSTAKA}

., 2011. Alkitab Deuterokanonika, Jakarta: Lembaga Alkitab Indonesia.

Ariarajah, S. Wesley., 2008. Tak Mungkin Tanpa Sesamaku Isu-Isu Dalam Relasi Antar Iman, Jakarta: Gunung Mulia.

Christy, Aysyah., 2012. Persiapan Finansial Menuju Mahligai Pernikahan, Jakarta: Elex Media Kumputindo.

Go, Piet., 1990. Kawin Campur Beda Agama Dan Beda Gereja, Malang: Dioma.

------. 1992., Pokok-pokok Soal Kawin Campur, Malang: Dioma.

Gunawan, H. Pidyarto., 2000. Umat Bertanya Romo Pid Menjawab, Yogyakarta: Kanisius.

Hadiwardoyo, Al Purwa., 1988. Perkawinan Dalam Tradisi Katolik, Yogyakarta: Kanisius.

Hardiwiratno, Y., 2008. Tanya Jawab Seputar Perkawinan, Yogyakarta: Kanisius.

Kriswanta, G., 2012. Sembilan Puluh Sembilan Tanya Jawab Tentang Perkawinan Secara Katolik, Yogyakarta: Kanisius.

KWI., 2011. Pedoman Pastoral Keluarga, Jakarta: Obor.

Prihartana, Agung., 2008. Pendidikan Iman Anak Dalam Keluarga Kawin Campur, Yogyakarta: Kanisius.

Priyanto, Yohanes Eko Dan Cornelius Triwidya Tjahja Utama., 2017. Lima Panca Tugas Gereja, Pelaksanaan, Keluarga Kristiani, Masyarakat Dan Gereja, Dalam Jurnal Pendidikan Agama Katolik Tahun 9 Tanggal 18 Oktober 2017 Hal 98-99.

Raharso, Catur Alf., 2006. Kesepakatan nikah dalam hukum perkawinan kanonik, Malang: Dioma.

Raho, Bernard., 2003. Keluarga Berziarah Lintas Zaman, Flores: Nusa Indah.

Reksosusilo, S., 1997. Reksa Pastoral Dalam Situasi Dewasa Ini, Malang: Dioma.

Rubiyatmoko, Robertus., 2011. Perkawinan Katolik Menurut KHK, Yogyakarta: Kanisius.

Sugiyono., 2006. Metode Penelitian Kualitatif, Bandung: Alfabeta.

Suparto., 2009. Kerukunan Umat Beragama, Eksistensi Umat Katolik Dalam Hidup Bernegara, Semangat Baru Dalam Menumbuhkan Sikap Kerukunan Umat Beragamadan Evangelisasi Baru Dalam Hidup Beragama, dalam Jurnal Pendidikan Agama Katolik Tahun 1 Tanggal 1 April 2009 Hal 39.

Supriyadi, Agustinus., 2018. Orang Tua, Anak Dan Pendidikan, dalam Jurnal Pendidikan Agama Katolik Tahun 10 Tanggal 19 April 2018 Hal 31.

Suwita., 2001. Tri Tugas Kristus dan Panca Tugas Gereja, Malang: Dioma.

-------., 2002. Bidang Kesaksian, Malang: Dioma.

------., 2002. Bidang Paguyuban, Malang: Dioma.

------., 2002. Bidang Pelayanan, Malang: Dioma.

Tondowidjojo, John., 1993. Persiapan Perkawinan. Surabaya: Sanggar Bina Tama.

Utami, Maria Goretti Dan Antonius Tse., 2018. Dewasa, Liturgi Dan Paroki, dalam Jurnal Pendidikan Agama Katolik Tahun 10 Tanggal 20 Oktober 2018 Hal 179. 